\title{
Prostaglandin E2 receptor EP1 (PGE2/EP1) deletion promotes glomerular podocyte and endothelial cell injury in hypertensive TTRhRen mice
}

\author{
Rania Nasrallah ${ }^{1}$. Joseph Zimpelmann ${ }^{1}$ - Susan J. Robertson ${ }^{2}$. Jamie Ghossein ${ }^{1}$. Jean-Francois Thibodeau ${ }^{3}$. \\ C. R. J. Kennedy $\mathbb{D}^{1,4} \cdot$ Alex Gutsol $^{4} \cdot$ Fengxia Xiao $^{4} \cdot$ Dylan Burger $\mathbb{D}^{4} \cdot$ Kevin D. Burns ${ }^{1,4} \cdot$ Richard L. Hébert ${ }^{1}$
}

Received: 19 June 2019 / Revised: 5 August 2019 / Accepted: 20 August 2019 / Published online: 16 September 2019

(C) United States \& Canadian Academy of Pathology 2019

\begin{abstract}
Prostaglandin E2 receptor EP1 ( $\left.\mathrm{PGE}_{2} / \mathrm{EP}_{1}\right)$ promotes diabetic renal injury, and $\mathrm{EP}_{1}$ receptor deletion improves hyperfiltration, albuminuria, and fibrosis. The role of $\mathrm{EP}_{1}$ receptors in hypertensive kidney disease (HKD) remains controversial. We examined the contribution of $\mathrm{EP}_{1}$ receptors to $\mathrm{HKD}$. $\mathrm{EP}_{1}$ null $\left(\mathrm{EP}_{1}{ }^{-l-}\right)$ mice were bred with hypertensive TTRhRen mice $(\mathrm{Htn})$ to evaluate kidney function and injury at 24 weeks. $\mathrm{EP}_{1}$ deletion had no effect on elevation of systolic blood pressure in $\mathrm{Htn}$ mice $\left(\mathrm{HtnEP}_{1}{ }^{-l-}\right)$ but resulted in pronounced albuminuria and reduced FITC-inulin clearance, compared with Htn or wild-type (WT) mice. Ultrastructural injury to podocytes and glomerular endothelium was prominent in $\mathrm{HtnEP}_{1}{ }^{-1}$ mice; including widened subendothelial space, subendothelial lucent zones and focal lifting of endothelium from basement membrane, with focal subendothelial cell debris. Cortex COX2 mRNA was increased by $\mathrm{EP}_{1}$ deletion. Glomerular $\mathrm{EP}_{3} \mathrm{mRNA}$ was reduced by $\mathrm{EP}_{1}$ deletion, and $\mathrm{EP}_{4}$ by $\mathrm{Htn}$ and $\mathrm{EP}_{1}$ deletion. In WT mice, $\mathrm{PGE}_{2}$ increased chloride reabsorption via $\mathrm{EP}_{1}$ in isolated perfused thick ascending limb (TAL), but $\mathrm{PGE}_{2}$ or $\mathrm{EP}_{1}$ deletion did not affect vasopressin-mediated chloride reabsorption. In WT and $\mathrm{Hth}$ mouse inner medullary collecting duct (IMCD), $\mathrm{PGE}_{2}$ inhibited vasopressin-water transport, but not in $\mathrm{EP}_{1}^{-1-}$ or $\mathrm{HtnEP}_{1}^{-1-}$ mice. Overall, $\mathrm{EP}_{1}$ mediated TAL and IMCD transport in response to $\mathrm{PGE}_{2}$ is unaltered in $\mathrm{Htn}$, and $\mathrm{EP}_{1}$ is protective in $\mathrm{HKD}$.
\end{abstract}

\section{Introduction}

Hypertension and diabetes are major causes of cardiovascular morbidity and mortality worldwide [1-3], and leading causes of chronic kidney disease, including hypertensive kidney disease (HKD) and diabetic kidney disease (DKD). Prostaglandin $\mathrm{E}_{2}\left(\mathrm{PGE}_{2}\right)$, the main renal product of cyclooxygenase 2 (COX2), stimulates renin secretion, and

Richard L. Hébert

rlhebert@uottawa.ca

1 Department of Cellular and Molecular Medicine, Faculty of Medicine, Kidney Research Centre, University of Ottawa, 451 Smyth Road, Room 2514, Ottawa, ON, Canada

2 Department of Pathology and Laboratory Medicine, Ottawa, ON, Canada

3 Prometic Biosciences Inc., Kidney Research Centre, Laval, QC, Canada

4 Ottawa Hospital Research Institute, Kidney Research Centre, University of Ottawa, Ottawa, ON, Canada regulates glomerular hemodynamics and tubular transport of salt and water, thereby contributing to blood pressure (BP) control [4, 5]. Inhibition of the $\mathrm{PGE}_{2}$ synthesis enzymes, cyclooxygenase (COX), and microsomal $\mathrm{PGE}_{2}$ synthase (mPGES1), causes hypertension [6-9]; but the contribution of $\mathrm{PGE}_{2}$ to $\mathrm{HKD}$ remains unclear.

Renal effects of $\mathrm{PGE}_{2}$ are mediated by four $\mathrm{G}$ protein coupled receptors, $\mathrm{EP}_{1-4}$. Both $\mathrm{COX} 2$ and $\mathrm{PGE}_{2}$ are elevated in diabetes $[4,10-16]$ and $\mathrm{EP}_{1}$ is upregulated in diabetic glomeruli and proximal tubules promoting renal injury [17]. Antagonizing or knocking out $\mathrm{EP}_{1}$ prevents diabetic hyperfiltration, kidney growth, and albuminuria $[17,18]$, suggesting that $\mathrm{EP}_{1}$ could be targeted to improve renal outcomes in DKD.

$\mathrm{EP}_{1}$ antagonism reduces $\mathrm{BP}$ in hypertensive type II diabetic $\mathrm{db} / \mathrm{db}$ mice [19]. However, in the stroke prone spontaneously hypertensive rat, a model of malignant hypertension, $\mathrm{EP}_{1}$ antagonism for 5 weeks reduced renal injury markers despite persistent hypertension [20]. Also, in a triple model of nephrectomized-deoxycorticosterone acetate (DOCA) salt-angiotensin II hypertension, $\mathrm{EP}_{1}$ deletion improved renal outcomes, but BP was also lowered 
[21]. We recently showed that $\mathrm{EP}_{1}$ deletion does not reduce BP in young renin overexpressing TTRhRen hypertensive mice [22]. We also recently demonstrated that $\mathrm{PGE}_{2} / \mathrm{EP}_{1}$ inhibits water and sodium reabsorption in the mouse inner medullary collecting duct (IMCD) and cortical collecting duct (CCD) [22]. Since the BP lowering effect of $\mathrm{EP}_{1}$ disruption is inconsistent, we sought to examine how $\mathrm{PGE}_{2}$ affects thick ascending limb (TAL) and IMCD transport, to gain insight into the transport properties of the distal nephron in $\mathrm{HKD}$, and the contribution of $\mathrm{PGE}_{2} / \mathrm{EP}_{1}$ receptors to renal injury and transport.

To gain mechanistic insight into the consequence of $\mathrm{EP}_{1}$ deletion in $\mathrm{HKD}$ versus $\mathrm{DKD}$, we bred $\mathrm{EP}_{1}$ null mice with TTRhRen hypertensive mice, and measured markers of renal function and injury. We report that hypertensive mice lacking $\mathrm{EP}_{1}$ have increased albuminuria and reduced GFR compared with wild-type hypertensive mice, but persistent hypertension, suggesting that renal $\mathrm{EP}_{1}$ protects against HKD via BP-independent mechanisms.

\section{Materials and methods}

\section{Mouse models}

All animal procedures were approved by the University of Ottawa Animal Care Committee. Mice were housed on a 12-h light-dark cycle, with free access to standard chow and water. Male mice were studied at 24 weeks of age. The contribution of $\mathrm{EP}_{1}$ was studied using $\mathrm{FVB} / \mathrm{n}$ mice with gene-targeted $\mathrm{EP}_{1}$ deletion $\left(\mathrm{EP}_{1}^{-1-}\right.$ mice). These mice were generated and characterized at the Kidney Research Centre [23]. Hyperreninemic hypertensive TTRhRen [24, 25] transgenic mice $(\mathrm{Htn})$ on the same $\mathrm{FVB} / \mathrm{n}$ background were bred with $\mathrm{EP}_{1}{ }^{-1-}$ to generate hypertensive mice lacking $\mathrm{EP}_{1}\left(\mathrm{HtnEP}_{1}{ }^{-l}\right)$. We examined the effect of $\mathrm{EP}_{1}$ deletion on hypertensive mice at 24 weeks. Mice were randomly assigned to four groups: wild type (WT), $\mathrm{EP}_{1}^{-/-}$, Htn, and $\mathrm{HtnEP}_{1}^{-/-}$.

\section{Blood pressure, metabolic cages, and urine analysis}

Systolic blood pressure (SBP) was measured at the same time daily by tail-cuff plethysmography (BP 2000, Visitech systems, NC, USA). Following a 5-day training period, the average SBP of 5 consecutive days was calculated as previously done $[22,26]$. Mice were placed in metabolic cages with free access to water and food. Twenty-four hours of food consumption, urine output, and water intake were recorded following a 24-h adaptation period. Urine osmolality was determined by freezing point depression (Advanced Model 3MO Plus Osmometer, Advanced Instruments Inc, MA, USA). Twenty-four hours of urine albumin was quantified by Mouse Albumin ELISA (Bethyl Labs, TX, USA) and arginine vasopressin (AVP) excretion rates were measured using $\mathrm{Arg}^{8}$-Vasopressin ELISA (Enzo Life Sciences, NY, USA) and corrected for 24-h urine output.

\section{Glomerular filtration rate (GFR)}

GFR was estimated in conscious mice prior to kill by fluorescein isothiocyanate (FITC)-inulin clearance. Briefly, $5 \%$ of FITC-inulin (Sigma-Aldrich, St. Louis, MO, USA) dissolved in $0.9 \%$ saline was dialyzed overnight and filtered. Mice were injected with $3.74 \mu \mathrm{l} / \mathrm{gBW}$ of FITC-inulin via tail vein. Blood was collected from the saphenous vein into heparinized capillary tubes at seven intervals: $3,7,10$, $15,35,55$, and $75 \mathrm{~min}$, and centrifuged. Samples were buffered in HEPES (500 mM, pH 7.4) and fluorescence was measured (excitation $488 \mathrm{~nm} /$ emission $538 \mathrm{~nm}$ ). GFR was calculated using a two-compartment clearance model as previously reported $[22,26]$.

\section{Quantitative PCR analysis}

The left kidneys were dissected to separate cortex and medulla, and snap frozen in liquid nitrogen. Glomeruli were separated from cortex as previously reported by our group [27], and 50 glomeruli per mouse were used to isolate RNA. Briefly the cortex was minced and digested in $10 \mathrm{ml}$ of perfusion solution containing $10 \mathrm{mg}$ collagenase type IV (Sigma, St. Louis, MO, USA) gassed with a $95 \% \mathrm{O}_{2}$ to $5 \%$ $\mathrm{CO}_{2}$ mixture at $37^{\circ} \mathrm{C}$. The digested mixture was serially sieved: 250,105 , and $75 \mu \mathrm{m}$. Individual glomeruli were isolated under the light microscope from the $75 \mu \mathrm{m}$ suspension. Snap frozen tissue was homogenized using the TP103 Amalgamator COE Capmixer (GC America Inc, IL, USA). The RNAqueous Mini Kit (Invitrogen, MA, USA) was used to extract RNA from glomeruli and tissue RNA was isolated with TRIzol (Invitrogen, MA, USA) and treated with DNAse I (Invitrogen, MA, USA). mRNA was measured by quantitative PCR (qPCR) with the ABI Prism 7000 system using specific primers as described, and the SYBR Advantage qPCR Premix (Clontech Laboratories, CA, USA) according to the manufacturer's instructions. The expression of $\mathrm{COX} 2, \mathrm{EP}_{1}, \mathrm{EP}_{3}$, and $\mathrm{EP}_{4}$ was examined. Expression was normalized to 18S RNA and the 2(-Delta$\operatorname{DeltaC}(\mathrm{T})$ ) method was used for analysis as done previously [22]. Table 1 lists the primers used for qPCR.

\section{Urine microparticle analysis}

Urinary microparticles were assessed from 24-h urine samples by flow cytometry as described previously with modification $[28,29]$. Briefly, urine samples were thawed rapidly and centrifuged at $2500 \times g$ for $10 \mathrm{~min}$ at $4{ }^{\circ} \mathrm{C}$ to remove any large debris. Supernatants were then transferred 
Table 1 Primer sequences for qPCR

\begin{tabular}{lll}
\hline Product name & Forward & Reverse \\
\hline 18S & 5'-ATGGTAGTCGCCGTGCCTAC-3' $^{\prime}$ & 5'-CCGGAATCGAACCCTGATT-3' $^{\prime}$ \\
EP1 receptor & 5'-AGTGCCAAGGGTGGTCCAA-3' $^{\prime}$ 5'-CCGGGAACTACGCAGTGAAC-3' $^{\prime}$ \\
EP3 receptor & 5'-GCCGCTATTGATAATGATGTTGAA-3' $^{\prime}$ & 5'-CCTTCTCCTTTCCCATCTGTGT-3' $^{\prime}$ \\
EP4 receptor & 5'-ATGGTCATCTTACTCATCGCCAC-3' $^{\prime}$ & 5'-CTTTCACCACGTTTGGCTGAT-3' $^{\prime}$ \\
COX2 & 5'-CAAGGGAGTCTGGAACATTG-3' & 5'-ACCCAGGTCCTCGCTTATGA-3' $^{\prime}$ \\
\hline
\end{tabular}

to a fresh tube and centrifuged for $20 \mathrm{~min}$ at $20,000 \times \mathrm{g}$ at $4{ }^{\circ} \mathrm{C}$. The resultant supernatant was discarded and the microparticle pellet was re-suspended in filtered Annexin V binding buffer (10 mM HEPES, pH 7.4, $140 \mathrm{mM} \mathrm{NaCl}$, $2.5 \mathrm{mM} \mathrm{CaCl} 2$ ). Microparticles were labeled with a FITCconjugated Annexin V (1:50 dilution, Biolegend, San Diego, CA, USA), and a Phycoerythrin (PE)-conjugated antipodoplanin antibody (1:100 dilution, Biolegend, San Diego, CA, USA) for $1 \mathrm{~h}$. A PE-conjugated isotype IgG and Annexin $\mathrm{V}$ in buffer lacking calcium were employed as negative controls. Samples were analyzed on a Beckman Coulter Cytoflex at the University of Ottawa Flow Cytometry Core Facility.

\section{Histology and electron microscopy}

Mice were euthanized at 24 weeks of age. Histopathological analysis was performed in a blinded manner, on paraffin embedded sections, $4 \mu \mathrm{m}$ thick. The glomerular area (GA) was manually traced as the area within the outer capillary loops of the tuft in 12-18 glomeruli per mouse (x63 magnification). The mean glomerular volume (GV) was calculated from the measured GA as follows: $\mathrm{GV}=$ (GA) $3 / 2 \times \beta / d$, where $\beta$ is a dimensionless shape coefficient ( $\beta=1.38$ for spheres) and $d=1.01$ is a size distribution coefficient that is used to adjust for variation in the glomerular size [30]. The capillary volume was measured as the volume of CD31-positive cells in the glomerulus. The capillary area (CA) stained positive to CD31 was quantified in 12-18 randomly selected glomeruli $(\times 63$ magnification). The capillary volume (CV) was calculated as follows: $\mathrm{CV}=(\mathrm{GV} \times \mathrm{CA}) / \mathrm{GA}$. The results were averaged for each animal. Microscopy was performed with a Zeiss AX10 microscope (Oberkochen, Germany). Images were analyzed with ImagePro Plus software (Media Cybernetics, Bethesda, MD, USA).

Ultrastructural analysis of the glomerular filtration barrier was assessed in the four hypertensive groups by electron microscopy (three mice per group) as previously described [11]. Briefly, kidney cortex (0.5 mm cubes) were fixed in $2.5 \%(\mathrm{w} / \mathrm{v})$ glutaraldehyde in phosphate buffered saline, placed into a Leica EM Tissue Processor, rinsed in cacodylate buffer, $2 \mathrm{~h}$ post fixation in $2 \%(\mathrm{w} / \mathrm{v})$ osmium tetroxide, dehydrated through graded ethanols and acetone, and infiltrated in three changes of Spurr's resin for $24 \mathrm{~h}$. Blocks were cured at $65^{\circ} \mathrm{C}$, sectioned $(80 \mu \mathrm{m})$ using a Leica Ultracut $\mathrm{R}$ ultramicrotome, stained with uranyl acetate/lead citrate, and screened on a Hitachi 7600 TEM. Images were captured using AMT digital camera software. Glomerular basement membranes (GBMs) were measured on images at $\times 30,000$ in zones with perpendicularly oriented foot processes. Between 30 and 140 measurements/mouse were made. At a magnification of $\times 10,000$ the GBM length was measured live with these images saved including the labeled measurement line. The peripheral open loops of entire glomeruli were sampled. Manual counting of foot processes along these measured lengths of GBM was done on the digital images. The slit pore diaphragm diameters were measured at $\times 60,000$ in regions with perpendicularly oriented foot processes.

\section{In vitro microperfusion studies in IMCD and mTAL}

Mice were euthanized at 24 weeks of age, and IMCD were microdissected for in vitro microperfusions and measurement of net fluid reabsorption $(\mathrm{Jv})$.

${ }^{3} \mathrm{H}$-inulin $(75 \mu \mathrm{Ci} / \mathrm{ml})$ was used as a volume marker. In control periods, two collections were made for calculation of basal Jv following $30 \mathrm{~min}$ equilibration. Tubules with a negative basal Jv were discarded. AVP $\left(10^{-12} \mathrm{mM}\right.$, SigmaAldrich, St. Louis, MO, USA) was added to the bath and four 10-min collections were made. $\mathrm{PGE}_{2}\left(10^{-7} \mathrm{mM}\right.$, Sigma-Aldrich, St. Louis, MO, USA) was then added with five additional 10-min collections. Mean Jv was calculated as previously described [22, 26].

For measurement of mTAL chloride flux, mTAL were microdissected and chloride transport was studied in the absence of stimulation (baseline transport). The effect of $\mathrm{PGE}_{2}$ on vasopressin-dependent chloride transport was studied with $10^{-6} \mathrm{mM} \mathrm{PGE}_{2}$ stimulations following $10^{-7} \mathrm{mM}$ AVP, which has been shown to stimulate TAL chloride transport [31]. Then experiments were repeated with $\mathrm{PGE}_{2}$ stimulations first, followed by $\mathrm{PGE}_{2}$ and AVP. Three collections were made for each period. Chloride concentrations were measured by microfluorometry (SPQ (6-Methoxy- $N$ (3Sulfopropyl) Quinolinium, Inner Salt); Molecular Probes, Eugene, OR, USA). 


\section{Characterization of hypertensive-diabetic mice lacking $\mathrm{EP}_{\mathbf{1}}$}

Another subset of the four mouse groups were rendered diabetic with streptozotocin toxin (STZ) injection at 6-8 weeks of age, namely: wild-type diabetic (STZ), EP 1 null diabetic $\left(\mathrm{STZEP}_{1}\right)$, hypertensive diabetic (STZHtn), and $\mathrm{EP}_{1}$ null hypertensive diabetic $\left(\mathrm{STZHtnEP}_{1}\right)$. Diabetes was induced with five-daily intraperitoneal injections of $50 \mathrm{mg} / \mathrm{kg}$ BW STZ (Sigma-Aldrich, St. Louis, MO). As a vehicle control, four mice from each nondiabetic group received $\mathrm{Na}$ citrate injections and were pooled with uninjected nondiabetic mice since no differences were observed in all the parameters measured. Diabetes induction was confirmed by blood glucose monitoring with a glucometer at 12 weeks of age. At 22 weeks of age, glucose was measured following a $16 \mathrm{~h}$ fast using a colorimetric assay as per the manufacturer's instructions (Glucose colorimetric assay Kit, Cayman Chemical, item no. 10009582).

Periodic acid-Schiff (PAS) staining and histopathological analyses were performed on diabetic mice. Glomerulosclerosis and tubulopathy was estimated on PAS-stained paraffin embedded sections, $4 \mu \mathrm{m}$ thick, in a blinded manner. Renal lesions were quantified using a conventional semi-quantitative scoring approach [29] with minor modifications. Glomerulopathy was assessed according to the extent of mesangial cell proliferation, hyalinosis, and sclerosis. The glomerular injury score (GIS) was graded $0-3+$, in which 0 was no injury, $1+$ was injury up to $25 \%$ of the glomerulus, $2+$ was $50 \%$, and $3+$ was injury of more than $50 \%$. The GIS was calculated as the mean of scores assigned to 30 glomeruli in each mouse. Tubulopathy was assessed for tubular dilation, accumulation of PAS-positive droplets and atrophy of tubular epithelium. Tubular lesions were graded from 0 to $3+$, according to the severity of tubular dilations, in at least ten microscopic fields in each section.

For immunohistochemistry, antigen retrieval was done with TRIS/EDTA buffer pH 9.0. Glomerular capillaries were identified by platelet endothelial cell adhesion molecule-1 (CD31) with rabbit anti-CD31 antibody (Invitrogen, Carlsbad, CA, USA), dilution 1:100. Visualization was performed with ImmPRESS kits (Vector Lab, Burlingame, CA, USA) and 3-3'-diaminobenzidine tetrahydrochloride.

\section{Statistics}

Graphpad Prism (San Diego, CA, USA) was used for data analysis. Values are expressed as means \pm SEM. Statistical analysis was done using parametric and nonparametric tests. One-way ANOVA followed by Tukey's post test and an unpaired $t$-test was performed for all experiments. The significance was indicated in results section for $p<0.05$ by ANOVA. For EM analyses we also performed Kruskal-Wallis test followed by Dunn's multiple comparison test, and Mann-Whitney test. In addition, a one sample $t$-test with a hypothetical value of 1 was performed for qPCR.

\section{Results}

\section{$E P_{1}$ deletion reduces glomerular filtration independent of blood pressure or volume status in hypertensive mice}

To study the effect of chronic hypertension (24 weeks) and $\mathrm{EP}_{1}$ receptor deletion on renal function, we measured glomerular filtration rate, kidney weights, volume status, and urine output. Body and kidney weights were unaltered in all
Table 2 Mouse parameters were measured at 24 weeks of age in four mouse groups: wild type (WT), EP1 null (EP1 $\left.1^{--}\right)$, hypertensive TTRhRen (Htn), and hypertensive EP1 null $\left(\mathrm{HtnEP}^{-/-}\right)$

\begin{tabular}{lrrrc}
\hline & \multicolumn{1}{l}{ WT } & \multicolumn{1}{c}{$\mathrm{EP}_{1}^{-l-}$} & \multicolumn{1}{c}{$\mathrm{Htn}$} & $\mathrm{HtnEP}_{1}^{-l-}$ \\
\hline Final body weight $(\mathrm{BW}, \mathrm{g})$ & $29.5 \pm 1.0$ & $29.8 \pm 1.0$ & $30.2 \pm 0.7$ & $29.0 \pm 0.5$ \\
Kidney weight $(\mathrm{KW}, \mathrm{g})$ & $199.2 \pm 8.8$ & $204.2 \pm 4.9$ & $219.7 \pm 9.5$ & $205.9 \pm 5.4$ \\
$\mathrm{KW} / \mathrm{BW}\left(\times 10^{3}\right)$ & $6.2 \pm 0.2$ & $6.4 \pm 0.2$ & $6.5 \pm 0.1$ & $6.7 \pm 0.1$ \\
Tibia length $(\mathrm{TL}, \mathrm{mm})$ & $18.0 \pm 0.3$ & $18.2 \pm 0.3$ & $18.0 \pm 0.1$ & $18.1 \pm 0.2$ \\
$\mathrm{KW} / \mathrm{TL}(\mathrm{g} / \mathrm{mm})$ & $11.1 \pm 0.5$ & $11.1 \pm 0.2$ & $11.1 \pm 0.3$ & $11.3 \pm 0.3$ \\
Food intake $(\mathrm{g} / \mathrm{day})$ & $3.6 \pm 0.1$ & $3.6 \pm 0.2$ & $3.5 \pm 0.2$ & $3.8 \pm 0.1$ \\
Water intake $(\mathrm{ml} / \mathrm{day})$ & $3.1 \pm 0.2$ & $3.8 \pm 0.2$ & $3.8 \pm 0.2$ & $4.8 \pm 0.3$ \\
Urine Volume $(\mathrm{ml} / \mathrm{day})$ & $0.70 \pm 0.05$ & $0.74 \pm 0.08$ & $1.14 \pm 0.07$ & $1.78 \pm 0.16$ \\
Urine Osmolality $\left(\times 10^{3} \mathrm{mOsm} / \mathrm{kg} \mathrm{H} \mathrm{H}_{2} \mathrm{O}\right)$ & $3.95 \pm 0.25$ & $3.58 \pm 0.15$ & $2.71 \pm 0.17^{*}$ & $1.95 \pm 0.10^{*} \%$ \\
Urine Vasopressin $\left(\mathrm{AVP} ; \times 10^{3} \mathrm{pg} / \mathrm{day}\right)$ & $1.01 \pm 0.20$ & $1.02 \pm 0.14$ & $1.61 \pm 0.18^{*}$ & $1.53 \pm 0.15^{*}$ \\
Urine Albumin $\left(\times 10^{3} \mathrm{\mu g} / \mathrm{day}\right)$ & $8.2 \pm 0.7$ & $8.3 \pm 1.5$ & $354.6 \pm 128.8$ & $1494.0 \pm 672.7$ \\
\hline
\end{tabular}

Data are presented as mean \pm SEM, $n=7-21$

${ }^{*} p<0.05$ vs WT; ${ }^{\&} p<0.05$ vs EP1; ${ }^{\%} p<0.05$ vs Htn 
hypertensive mice compared with WT, and kidney weights normalized to body weight or tibia length were also unchanged (Table 2). Food and water consumption were unchanged in $\mathrm{EP}_{1}{ }^{-l-}$, $\mathrm{Htn}$, and $\mathrm{HtnEP}_{1}{ }^{-/-}$compared with WT, but urine osmolality was significantly lower in $\mathrm{Htn}$ mice and $\mathrm{HtnEP}_{1}{ }^{-1-}$ mice compared with WT.

To examine whether $\mathrm{EP}_{1}$ receptor deletion affected urinary AVP excretion, we measured AVP levels in urine collected for $24 \mathrm{~h}$. AVP excretion rates were increased in $\mathrm{Htn}\left(1.61 \pm 0.18 \times 10^{3} \mathrm{pg} /\right.$ day $)$ and $\mathrm{HtnEP}_{1}{ }^{-/-}(1.53 \pm 0.15)$ compared with WT mice $(1.01 \pm 0.20)$, and unaltered by $\mathrm{EP}_{1}$ deletion (Table 2).

To examine whether $\mathrm{EP}_{1}$ receptor deletion affected urinary albumin excretion, we measured albumin levels in urine collected for $24 \mathrm{~h}$. As shown in Table 2, albuminuria was comparable in $\mathrm{EP}_{1}^{-l-}(8.3 \pm 1.5 \mu \mathrm{g} /$ day $)$ and WT $(8.2 \pm$ $0.7 \mu \mathrm{g} /$ day) mice.

In Fig. 1, systolic BP was significantly higher in $\mathrm{Htn}$ $(143.1 \pm 2.8 \mathrm{mmHg})$ and $\mathrm{HtnEP}_{1}^{-1-}(147.9 \pm 3.3 \mathrm{mmHg})$ compared with WT $(114.3 \pm 2.7 \mathrm{mmHg})$. $\mathrm{EP}_{1}$ deletion did not affect BP compared with WT. Glomerular filtration rate was unchanged in $\mathrm{EP}_{1}^{-1-}(243.0 \pm 31.1 \mu \mathrm{l} / \mathrm{min})$ and $\mathrm{Htn}$ mice $(230.7 \pm 28.1 \mu \mathrm{l} / \mathrm{min})$ compared with WT $(245.8 \pm$ $23.1 \mu \mathrm{l} / \mathrm{min}$ ), but significantly reduced in $\mathrm{HtnEP}_{1}{ }^{-1-}$ mice $(164.5 \pm 24.9 \mu \mathrm{l} / \mathrm{min})$.

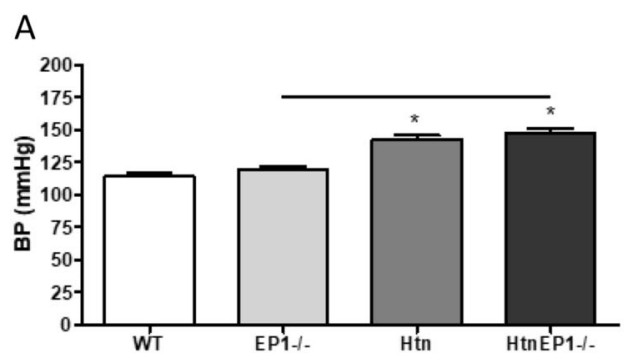

Fig. 1 Systolic blood pressure (BP, $n=10-21$ ) and FITC-inulin clearance $(n=7-13)$ were measured in four mouse groups: wild type (WT), EP $\mathrm{EP}_{1}$ null $\left(\mathrm{EP}_{1}^{---}\right)$, hypertensive TTRhRen $(\mathrm{Htn})$, and
Renal COX2, $E P_{1}, E P_{3}$, and $E_{4}$ are altered in HKD

To study the effect of $\mathrm{EP}_{1}$ deletion on expression of the renal COX2/PGE $2 / E P$ receptor system in $\mathrm{HKD}$ and $\mathrm{DKD}$, we performed qPCR analysis on renal cortex and medulla, as well as microdissected glomeruli. As shown in Fig. 2, the expression of cortical COX2 was unchanged in Htn mice $\left(1.5 \pm 0.3\right.$-fold WT), but increased in mice lacking $\mathrm{EP}_{1}$, to $2.2 \pm 0.1$-fold WT in $\mathrm{EP}_{1}^{-1-}$, and $2.5 \pm 0.6$-fold WT in $\mathrm{HtnEP}_{1}{ }^{-1-}$. Medullary COX2 expression was comparable in all groups (data not shown). In microdissected glomeruli, $\mathrm{EP}_{1}$ expression was unchanged in $\mathrm{Htn}$ mice (data not shown). Similarly, $\mathrm{EP}_{3}$ receptors were unchanged in $\mathrm{Htn}$ mice, but significantly reduced by $75 \%$ in mice lacking $\mathrm{EP}_{1}$ receptors $\left(\mathrm{EP}_{1}^{-l-}\right.$ and $\left.\mathrm{HtnEP}_{1}^{-l-}\right) . \mathrm{EP}_{3}$ expression was also significantly lower in $\mathrm{HtnEP}_{1}^{-l-}$ mice compared with $\mathrm{Htn}$. Glomerular $\mathrm{EP}_{4}$ receptors were reduced in all mouse groups up to $90 \%$ compared with WT.

\section{$E P_{1}$ deletion alters urinary microparticle excretion in HKD}

Microparticles are emerging biomarkers of cellular stress/ injury. To study the effect of $\mathrm{EP}_{1}$ deletion on urinary microparticle levels in HKD, we characterized the origin of

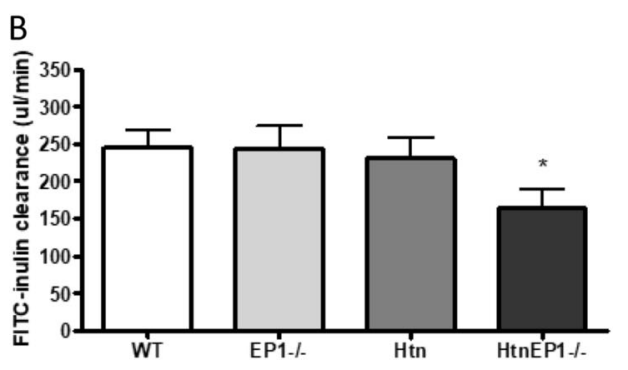

hypertensive $\mathrm{EP}_{1}$ null $\left(\mathrm{HtnEP}_{1}^{-l-}\right)$. Data are presented as mean \pm SEM. $p<0.05 *$ vs WT. Line indicates significance between groups
A

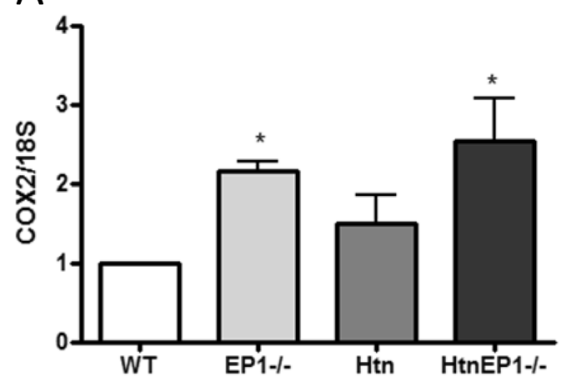

B

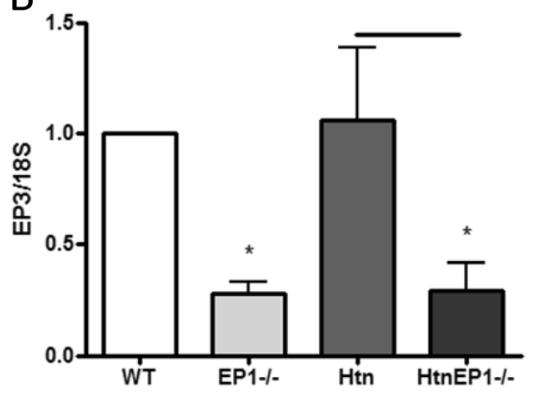

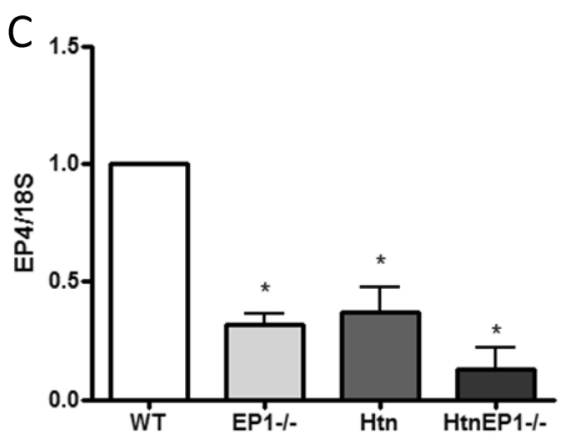

Fig. 2 Quantitiative PCR analysis of COX2 in the cortex (a, $n=5-9)$ was performed in four mouse groups at 24 weeks of age: wild type (WT), EP1 null $\left(\mathrm{EP}_{1}^{-l-}\right)$, hypertensive TTRhRen $(\mathrm{Htn})$, and hypertensive EP1 null $\left(\mathrm{HtnEP}_{1}^{-l-}\right) . \mathrm{EP}_{3}(\mathbf{b})$ and $\mathrm{EP}_{4}$ (c) receptors were measured in microdissected glomeruli $(n=5-6)$. Data were normalized to $18 \mathrm{~S}$ and presented as fold change of mean \pm SEM. $* p<0.05$ vs WT, black line indicates significance between groups 
the urine microparticles by flow cytometry using podoplanin (podocyte-derived) and annexin V labeling (all sources). Total Annexin V-labeled microparticles were not significantly different in all groups compared with WT mice $\left(4.6 \pm 1.2 \times 10^{9} /\right.$ $\mathrm{mg}$ creatinine), however there was $\sim 65 \%$ less urinary microparticles from $\mathrm{HtnEP}_{1}{ }^{-l-}\left(2.2 \pm 0.4 \times 10^{9} / \mathrm{mg}\right.$ creatinine $)$ compared with $\mathrm{EP}_{1}^{-1-}\left(6.3 \pm 1.1 \times 10^{9} / \mathrm{mg}\right.$ creatinine $)$ mice $(P=0.004)$. Similarly, podoplanin positive microparticles were not significantly different between all groups compared with wild-type mice, but again levels were reduced in $\mathrm{HtnEP}_{1}{ }^{-1-}\left(7.8 \pm 1.4 \times 10^{7} / \mathrm{mg}\right.$ creatinine) compared with $\mathrm{EP}_{1}^{-/-}\left(2.0 \pm 0.5 \times 10^{8} / \mathrm{mg}\right.$ creatinine $)$ mice $(P=0.03)$.

\section{$E P_{1}$ deletion promotes injury in HKD}

PAS-stained sections were scored for glomerular and tubular injury. Glomerular injury was undetectable in WT, $\mathrm{EP}_{1}^{-l-}$, and $\mathrm{Htn}$ mice, and negligible in $\mathrm{HtnEP}_{1}^{-l-}$ mice (data not shown). Therefore, to assess ultrastructural injury, we performed electron microscopy analyses of the glomerulus and filtration barrier of hypertensive mice. As shown in Fig. 3a-c, ultrastructural injury to podocytes and glomerular endothelium was prominent in $\mathrm{HtnEP}_{1}^{-/-}$ compared with WT mice, with podocyte vacuolation and foot process widening. The endothelium was lifted from the
GBM, and the subendothelial space was widened with electron-lucent fluffy material and focal cell debris. Overall there were no morphological anomalies in WT or $\mathrm{EP}_{1}^{-/-}$ mice. Two Htn mice showed short run or patchy foot process fusion and one mouse showed focal podocyte vacuoles, but all three Htn mice showed microvesicle blebs. Average foot processes lengths are shown in Fig. 3d, with increased length in $\mathrm{EP}_{1}^{-1-}$ mice from $302.2 \pm 12.5 \mathrm{~nm}$ in WT to $431.1 \pm 15.4 \mathrm{~nm}$, although this did not reach statistical significance. As shown in Fig. 3e, the GBM thickness was significantly reduced in $\mathrm{EP}_{1}^{-1-}$ mice from $188.1 \pm 6.9 \mathrm{~nm}$ in WT mice to $164.7 \pm 3.0 \mathrm{~nm}$. However, GBM thickness was significantly elevated in $\mathrm{HtnEP}_{1}^{-1-}$ mice $(215.2 \pm 10.5)$ compared with $\mathrm{EP}_{1}{ }^{-1-}$ and Htn mice. Finally, in Fig. 3f, slit pore diameters are increased in mice lacking $\mathrm{EP}_{1}$, from $0.030 \pm 0.001 \mu \mathrm{m}$ in WT to $0.041 \pm 0.001$ and $0.041 \pm 0.002$ in $\mathrm{EP}_{1}^{-/-}$and $\mathrm{HtnEP}_{1}^{-/-}$, respectively.

\section{$\mathrm{PGE}_{2} / \mathrm{EP}_{1}$ stimulates water and chloride transport in IMCD and MTAL}

The main site of renal $\mathrm{EP}_{1}$ expression is in the collecting duct (CD), where $\mathrm{PGE}_{2} / \mathrm{EP}_{1}$ activation promotes diuresis and natriuresis. We measured fluid reabsorption (Jv) in the IMCD and chloride flux in the mTAL, in response to $\mathrm{PGE}_{2}$
A

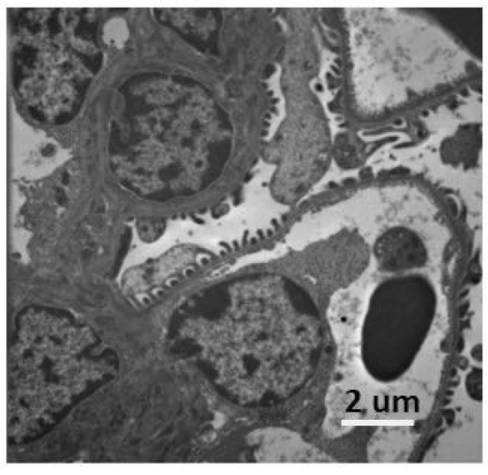

D

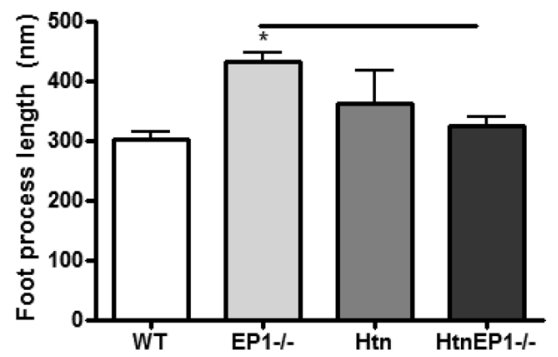

B

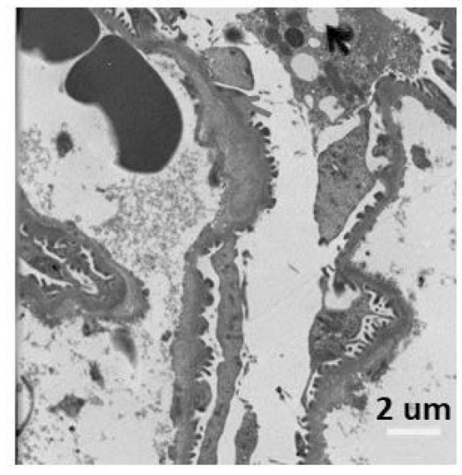

$\mathrm{E}$

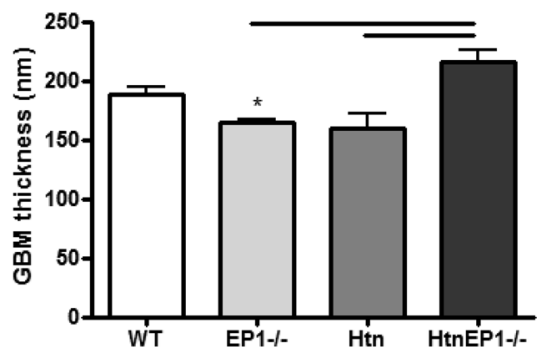

C

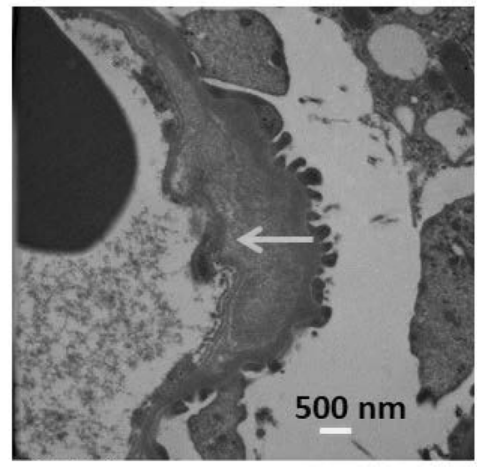

$\mathrm{F}$

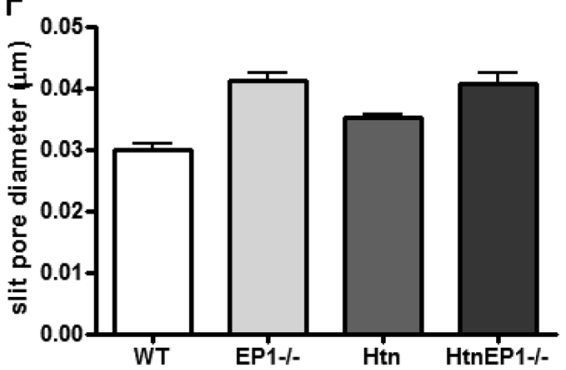

Fig. 3 Electron microscopy analysis at 24 weeks in four mouse groups: wild type (WT), $\mathrm{EP}_{1}$ null $\left(\mathrm{EP}_{1}^{---}\right)$, hypertensive TTRhRen (Htn), and hypertensive $\mathrm{EP}_{1}$ null $\left(\mathrm{HtnEP}_{1}^{-l-}\right)$. a Representative micrograph of wild-type control at $10,000 \times$; b Representative micrograph of $\mathrm{HtnEP}_{1}{ }^{-l-}$ mouse at $8000 \times$ showing podcyte vacuolation (red arrow) and foot process widening (blue arrow); c same image as B showing endothelial degeneration, lifting from glomerular basement membrane, and subendothelial insudate at $17,000 \times$ (green arrow). Average d foot process length $(n=3)$; e glomerular basement membrane thickness $(n=3)$; and $\mathbf{f}$ slit pore diameters $(n=2-3)$ are shown as mean \pm SEM. $* p<0.05$ vs WT, and black line indicates significance between groups 

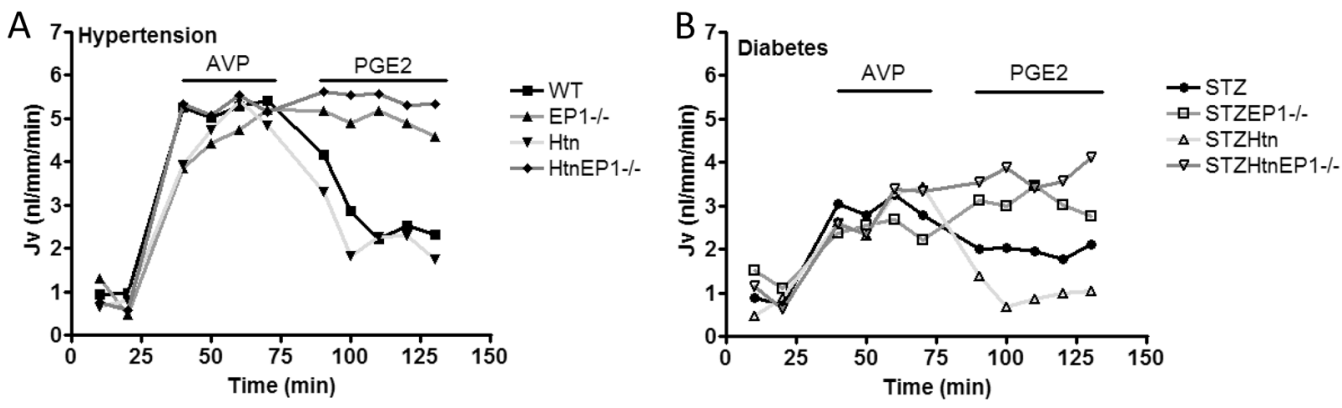

AVP

AVP+PGE2
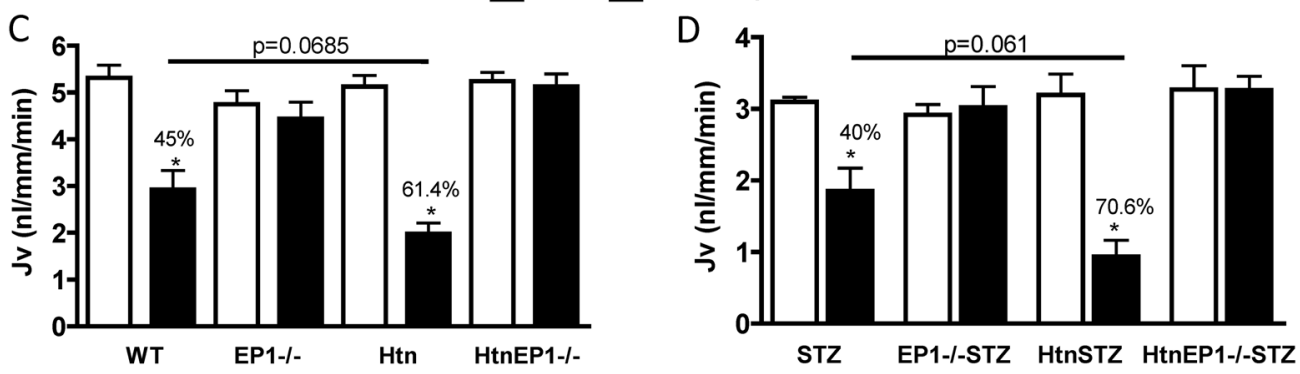

Fig. 4 Net fluid reabsorption (Jv) was analyzed in eight mouse groups with hypertension (HTn) and/or streptozotocin (STZ) diabetes: wild type (WT and STZ), EP1 null $\left(\mathrm{EP}_{1}{ }^{-l-}\right.$ and $\left.\mathrm{STZEP}_{1}{ }^{-l-}\right)$, hypertensive TTRhRen (Htn and STZHtn), and hypertensive EP1 null $\left(\mathrm{HtnEP}_{1}{ }^{-l-}\right.$ and $\left.\mathrm{STZHtnEP}{ }^{-1-}\right)$. The terminal inner medullary collecting ducts were microdissected for in vitro microperfusion and determination of $\mathrm{JV}(\mathrm{nl} / / \mathrm{mm} / \mathrm{min})$. A representative time course in minute ( $\mathrm{min}$ ) of $\mathrm{Jv}$ is shown for hypertension (a) and diabetes (b), the stimulation period in

absence (AVP) and presence of $\mathrm{PGE}_{2}$ is indicated with black line above the tracings. Bar graphs are shown for hypertension (c) and diabetes (d) of mean \pm SEM, $n=3-9$. Tubules were stimulated with $10^{-12} \mathrm{M}$ vasopressin (AVP: white bars) and AVP with $10^{-7} \mathrm{M} \mathrm{PGE}_{2}$ : black bars). Asterisk symbol indicates significance versus AVP, $p<$ 0.05 , and black line indicates significance between two groups with respective $p$-value

stimulation in the presence or absence of AVP. $\mathrm{PGE}_{2}$ inhibits AVP-mediated fluid reabsorption in microdissected terminal IMCD. A representative tracing of $\mathrm{Jv}$ over time is shown for one IMCD from each group (Fig. 4). As shown in Fig. $4 \mathrm{c}$, AVP increased $\mathrm{JV}$ to $5.3 \pm 0.3 \mathrm{nl} / \mathrm{mm} / \mathrm{min}$ in WT IMCD, but the AVP response was comparable in the other nondiabetic groups. $\mathrm{PGE}_{2}$ significantly attenuated AVPmediated Jv by $45 \%$ in WT $(2.9 \pm 0.4)$ and $61.4 \%$ in Htn mice $(2.0 \pm 0.2)$ compared with AVP alone, but not in $\mathrm{EP}_{1}^{-1-}(4.4 \pm 0.4)$ or $\mathrm{HtnEP}_{1}^{-l-}(5.1 \pm 0.3)$ mice. In STZ mice shown in Fig. 4d, AVP-stimulated Jv was $42 \%$ lower than WT mice only reaching $3.1 \pm 0.1 \mathrm{nl} / \mathrm{mm} / \mathrm{min}$. Again, the AVP response was comparable in all diabetic groups. $\mathrm{PGE}_{2}$ also attenuated AVP-mediated Jv by 40 and $70.6 \%$ in STZ $(1.9 \pm 0.3)$ and STZHtn $(0.9 \pm 0.2)$ mice respectively, but not in mice lacking $\mathrm{EP}_{1}$.

We examined whether the transport properties of the TAL are altered in long-standing HKD, and whether $\mathrm{PGE}_{2} / \mathrm{EP}_{1}$ is involved in TAL chloride transport. As shown in Fig. 5, AVP significantly increased chloride transport, from $67.1 \pm 8.8 \mathrm{pmol} / \mathrm{mm} / \mathrm{min}$ to $163.9 \pm 17.1$ in WT mice. There was no difference in the magnitude of the AVP response in the four groups, and $\mathrm{PGE}_{2}$ and $\mathrm{EP}_{1}$ deletion had no effect on AVP-mediated chloride reabsorption. In a second set of experiments, when $\mathrm{PGE}_{2}$ was added prior to AVP stimulation, $\mathrm{PGE}_{2}$ significantly
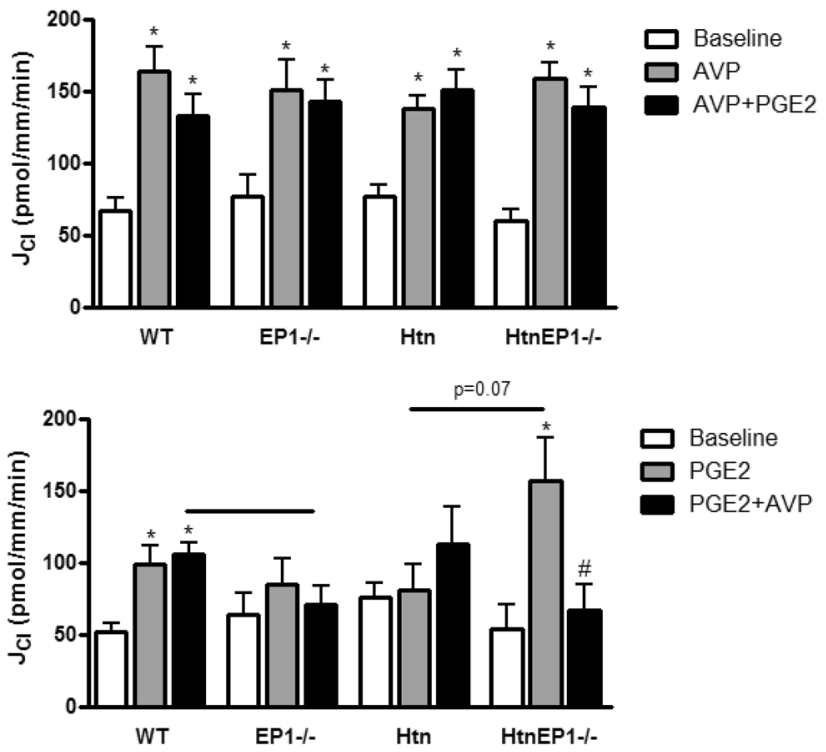

Fig. 5 Choride reabsorption $\left(\mathrm{J}_{\mathrm{C} 1}\right)$ was analyzed in four mouse groups: wild type (WT), $\mathrm{EP}_{1}$ null $\left(\mathrm{EP}_{1}^{-l-}\right)$, hypertensive TTRhRen (Htn), and hypertensive $\mathrm{EP}_{1}$ null $\left(\mathrm{HtnEP}_{1}{ }^{--}\right)$. The medullary thick ascending limb were microdissected for in vitro microperfusion and determination of $\mathrm{J}_{\mathrm{C} 1}(\mathrm{pmol} / \mathrm{mm} / \mathrm{min})$. The upper graph shown chloride reabsorption in response to $10^{-6} \mathrm{M}$ vasopressin (AVP) then $10^{-6} \mathrm{M} \mathrm{PGE}_{2}$ in the presence of AVP $(n=4-6)$. In the lower graph $\mathrm{PGE}_{2}$ was added first followed by AVP in the presence of $\mathrm{PGE}_{2}(n=4)$. Data are shown as mean \pm SEM. $* p<0.05$ vs baseline, ${ }^{*} p<0.05$ vs $\mathrm{PGE}_{2}$, and black line $p<0.05$ between two groups or respective $p$-value 
increased chloride reabsorption from $51.4 \pm 5.9$ to $98.9 \pm$ $12.9 \mathrm{pmol} / \mathrm{mm} / \mathrm{min}$ in WT mice. As shown, when AVP was added to WT mice following $\mathrm{PGE}_{2}$ stimulations, the magnitude of the AVP response was lower than the first set of experiments, and chloride reabsorption was only increased twofold by AVP, reaching 105.9 $\pm 8.2 \mathrm{pmol} /$ $\mathrm{mm} / \mathrm{min}$. The baseline chloride transport did not differ between groups, and the response to $\mathrm{PGE}_{2}$ was also similar. $\mathrm{EP}_{1}$ deletion attenuated AVP-stimulated chloride reabsorption following $\mathrm{PGE}_{2}$ stimulation from $105.9 \pm 8.2$ in WT mice to $71.1 \pm 12.1$ and $66.9 \pm 17.8$ in $\mathrm{EP}_{1}^{-1-}$ and $\mathrm{HtnEP}_{1}^{-/-}$mice, respectively. The AVP response post$\mathrm{PGE}_{2}$ was comparable in Htn $(112.2 \pm 26.4)$ and WT $(105.9 \pm 8.2)$ mice. However, in $\mathrm{HtnEP}_{1}{ }^{-/-}$mice, $\mathrm{PGE}_{2^{-}}$ mediated chloride transport was increased to $156.3 \pm 30.2$ compared with $98.9 \pm 12.9$ in WT mice, and there was a significant $50 \%$ attenuation of chloride transport upon costimulation with $\mathrm{PGE}_{2}+\mathrm{AVP}(66.9 \pm 17.8)$ compared with $\mathrm{PGE}_{2}$ alone $(112.2 \pm 26.4)$.

\section{$E P_{1}$ deletion is protective in DKD}

To compare the effect of $\mathrm{EP}_{1}$ deletion in the nondiabetic state with diabetes, we analyzed certain renal parameters in mice rendered diabetic by streptozotocin (STZ) injection (shown in Table 3) and compared them with renal parameters of nondiabetic mice shown in Table 2. As shown in Table 3, diabetic hyperglycemia was not affected by $\mathrm{EP}_{1}$ deletion or hypertension, but all diabetic mice were hyperglycemic compared with nondiabetic WT mice levels of $6.40 \pm 1.02 \mathrm{mg} / \mathrm{dL}$.
Body weights were reduced, and kidney weights were increased in all diabetic mice. As shown in Table $3, \mathrm{EP}_{1}$ deletion did not affect kidney to body or kidney to tibia length ratios in diabetic mice, but kidney to tibia length ratio was significantly lower in $\mathrm{STZHtnEP}_{1}^{-/-}$compared with STZ mice, from $16.4 \pm 0.6$ to $13.3 \pm 0.8$. Diabetic mice consumed about twofold more chow than nondiabetics. Food intake was significantly lower in $\mathrm{STZEP}_{1}^{-1-}$ and $\mathrm{STZHtnEP}_{1}^{-1-}$ mice compared with STZ mice. In diabetic mice water intake was up to tenfold higher than nondiabetics, but $\mathrm{EP}_{1}$ deletion significantly reduced water intake in $\mathrm{STZEP}_{1}^{-/-}$and $\mathrm{STZHtnEP}_{1}^{-1-}$ compared with STZ mice.

Urine volume was increased almost 50-fold in STZ mice compared with WT, but significantly reduced in $\mathrm{STZEP}_{1}^{-/-}$ mice. This reduction was reversed in $\mathrm{STZHtnEP}_{1}^{-/-}$mice. In all diabetic mice, urine osmolalities were reduced compared with nondiabetics, but also STZHtn and $\mathrm{STZHtnEP}_{1}{ }^{-1-}$ osmolalities were significantly lower than their respective controls (Htn and $\mathrm{HtnEP}_{1}^{-1-}$ ).

AVP excretion rates were increased in STZ mice 20-fold, but significantly reduced in $\mathrm{STZEP}_{1}{ }^{-/}(10.84 \pm 2.80)$, STZHtn $(13.57 \pm 3.22)$, and $\mathrm{STZHtnEP}_{1}{ }^{-/}(12.70 \pm 2.16)$ compared with STZ mice $(21.63 \pm 3.70)$. AVP excretion rates in diabetic mice were all also significantly higher than their respective controls. Albumin was significantly increased in STZHtn mice $(19180 \pm 5501)$ compared with WT and STZ mice. In diabetic mice, BP was increased to $134.7 \pm 4.4 \mathrm{mmHg}$ and slightly more in STZHtn mice $(151.4 \pm 3.8)$ but was not significantly different than STZ alone. STZ mice were hyperfiltering to $551.8 \pm 28.1$

Table 3 Mouse parameters were measured at 24 weeks of age in four mouse groups with streptozotocin (STZ) diabetes: wild type (STZ), EP1 null $\left(\mathrm{STZEP}_{1}{ }^{--}\right)$, hypertensive TTRhRen $(\mathrm{STZHtn})$, and hypertensive $\mathrm{EP}_{1}$ null $\left(\mathrm{STZHtnEP}_{1}{ }^{-l-}\right)$

\begin{tabular}{|c|c|c|c|c|}
\hline & STZ & $\mathrm{STZEP}_{1}^{-/-}$ & STZHtn & $\mathrm{STZHtnEP}_{1}^{-/-}$ \\
\hline Fasting blood glucose (mg/dL) & $31.14 \pm 0.81$ & $30.82 \pm 0.48$ & $26.70 \pm 1.70$ & $29.00 \pm 1.40$ \\
\hline Final body weight $(\mathrm{BW}, \mathrm{g})$ & $26.0 \pm 0.6$ & $25.0 \pm 0.9$ & $26.0 \pm 0.6$ & $24.3 \pm 0.7$ \\
\hline Kidney weight $(\mathrm{KW}, \mathrm{g})$ & $304.2 \pm 9.4$ & $261.9 \pm 16.6$ & $279.7 \pm 58.1$ & $238.7 \pm 14.8^{\#}$ \\
\hline $\mathrm{KW} / \mathrm{BW}\left(\times 10^{3}\right)$ & $10.3 \pm 0.2$ & $8.9 \pm 0.6^{\#}$ & $10.6 \pm 0.2$ & $9.4 \pm 0.3$ \\
\hline Tibia length (TL, mm) & $18.6 \pm 0.2$ & $18.1 \pm 0.2$ & $18.4 \pm 0.2$ & $18.0 \pm 0.2$ \\
\hline $\mathrm{KW} / \mathrm{TL}(\mathrm{g} / \mathrm{mm})$ & $16.4 \pm 0.6$ & $14.5 \pm 0.9$ & $15.0 \pm 0.8$ & $13.3 \pm 0.8^{\#}$ \\
\hline Food intake (g/day) & $8.4 \pm 0.2$ & $6.3 \pm 0.6^{\#}$ & $7.9 \pm 0.5$ & $7.0 \pm 0.4^{\#}$ \\
\hline Water intake (ml/day) & $40.9 \pm 1.5$ & $23.1 \pm 4.6^{\#}$ & $34.0 \pm 3.4$ & $34.2 \pm 3.1^{\#, \$}$ \\
\hline Urine Volume (ml/day) & $33.38 \pm 1.22$ & $18.31 \pm 4.40^{\#}$ & $28.21 \pm 3.25$ & $29.44 \pm 2.63^{\$}$ \\
\hline Urine Osmolality $\left(\times 10^{3} \mathrm{mOsm} / \mathrm{kg} \mathrm{H}_{2} \mathrm{O}\right)$ & $1.03 \pm 0.02$ & $1.20 \pm 0.12$ & $1.06 \pm 0.06$ & $0.99 \pm 0.03$ \\
\hline Urine Vasopressin (AVP; $\times 10^{3} \mathrm{pg} /$ day $)$ & $21.63 \pm 3.70$ & $10.84 \pm 2.80^{\#}$ & $13.57 \pm 3.22^{\#}$ & $12.70 \pm 2.16^{\#}$ \\
\hline Urine Albumin $\left(\times 10^{3} \mu \mathrm{g} / \mathrm{day}\right)$ & $75.4 \pm 33.4$ & $4.72 \pm 1.5$ & $19180.0 \pm 5501.0^{\#}$ & $10315.0 \pm 3177.0$ \\
\hline FITC-inulin clearance $(\mu 1 / \mathrm{min})$ & $551.8 \pm 28.1$ & $385.4 \pm 53.6$ & $381.9 \pm 45.3$ & $302.4 \pm 33.5$ \\
\hline Systolic blood pressure $(\mathrm{mmHg})$ & $134.7 \pm 4.4$ & $125.0 \pm 3.2$ & $151.4 \pm 3.8$ & $144.3 \pm 6.3$ \\
\hline
\end{tabular}

Data are presented as mean \pm SEM, $n=3-9$

${ }^{\#} p<0.05$ vs STZ; ${ }^{\$} p<0.05$ vs $\operatorname{STZEP}_{1}{ }^{-1-}$ 
compared with WT, but GFR was significantly lowered in STZEP $_{1}{ }^{-1-}(385.4 \pm 53.6), \quad$ STZHtn $(381.9 \pm 45.3)$ and $\mathrm{STZHtnEP}_{1}{ }^{-l-}(302.4 \pm 33.5)$ compared with STZ alone.

In Fig. 6 injury in diabetic mice was quite prominent unlike nondiabetic mice (data not shown). In STZ mice, very mild glomerular injury was observed with an average score of $0.9 \pm 0.2$. The score was comparable in STZEP $_{1}{ }^{-l-}$ mice $(0.9 \pm 0.2)$. In STZHtn mice, the mean injury score was significantly increased to $1.7 \pm 0.5$. Finally, in the $\mathrm{STZHtnEP}_{1}{ }^{-1-}$ mice, glomerular injury was significantly increased up to $2.3 \pm 0.5$. Tubule dilatation and injury were also scored from $0-3+$. A mild score was observed in WT mice $(0.2 \pm 0.1), \mathrm{EP}_{1}{ }^{-l-}$ mice $(0.3 \pm$ $0.2)$, Htn mice $(0.4 \pm 0.2)$, and $\mathrm{HtnEP}_{1}{ }^{-l-}$ mice $(0.6 \pm$ 0.2). In Fig. 6, tubule dilatation and injury are shown for diabetic mice. All $8 \mathrm{STZ}$ mice $(1.9 \pm 0.2)$ showed signs of injury, and even greater in STZHtn $(2.5 \pm 0.3)$ and $\mathrm{STZHtnEP}_{1}{ }^{-l-}(2.2 \pm 0.3)$ mice. The injury was slightly lower in $\mathrm{STZEP}_{1}{ }^{-1-}$ mice $(1.4 \pm 0.4)$ compared with STZ, but the difference was not significant. There was no significant difference by ANOVA in overall injury scores between diabetic groups.

CD31 labeling was used to examine CV. Mean CV was $52107 \pm 10036 \mu^{3}$ in WT mice, and unchanged in all nondiabetic groups (data not shown). As shown in Fig. 7, CV was elevated in STZ $(108702 \pm 6117)$ and STZHtn $(96922 \pm 10998)$ mice compared with WT. STZEP $_{1}{ }^{-1-}$ mice $(70093 \pm 5883)$ had significantly reduced CVs compared with STZ mice, but STZHtn and STZHtnEP ${ }^{-1-}$ volumes were no different than STZ. GVs were also measured and followed the same pattern of change as CVs in the different groups.
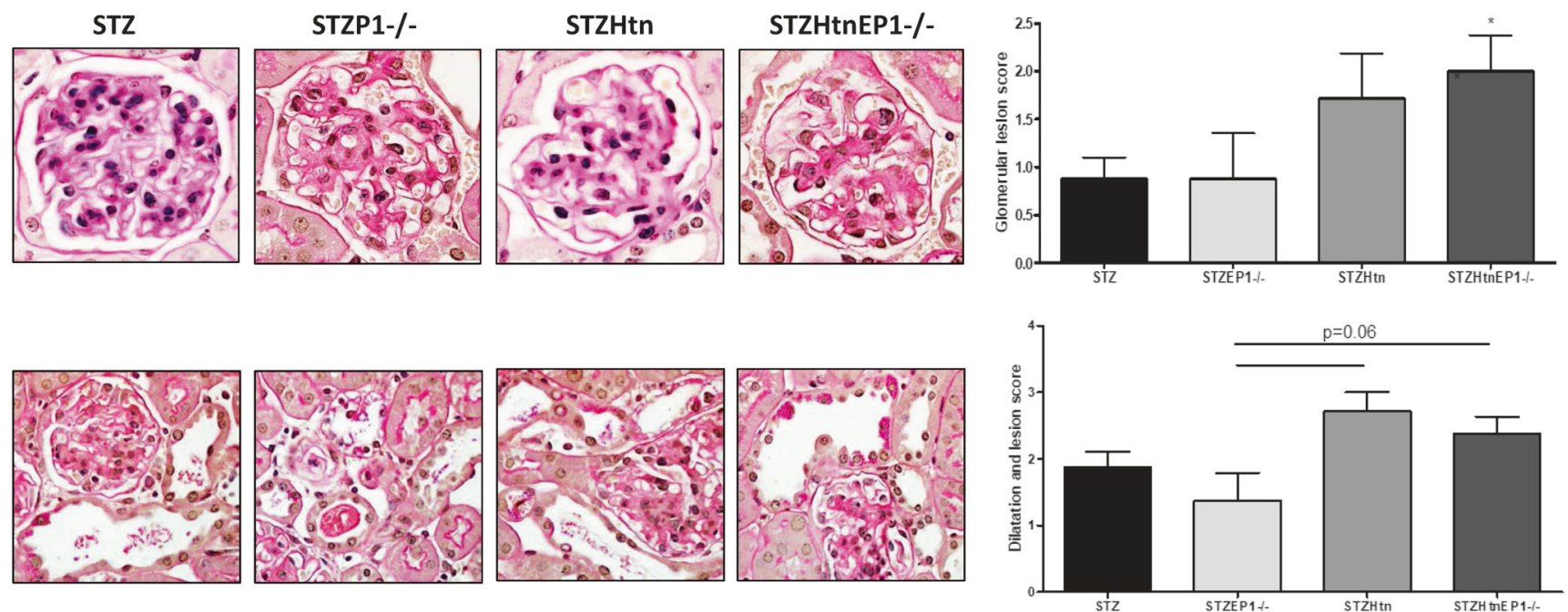

Fig. 6 Representative images for glomerular lesions (top) and tubular dilation/lesions (bottom) were scored on PAS-stained sections $(\times 63)$ and $(\times 40)$, respectively, taken at 24 weeks of age from four mouse groups with streptozotocin (STZ) diabetes: wild type (STZ), $\mathrm{EP}_{1}$ null $\left(\mathrm{STZEP}_{1}{ }^{-l-}\right)$, hypertensive TTRhRen $(\mathrm{STZHtn})$, and hypertensive $\mathrm{EP}_{1}$

\section{Discussion}

The contribution of $\mathrm{PGE}_{2} / \mathrm{EP}_{1}$ to $\mathrm{HKD}$ is unclear. We previously showed that $\mathrm{EP}_{1}$ deletion improves hyperfiltration, albuminuria, and fibrosis in several diabetic models [17]. The purpose of this study was to examine the contribution of $\mathrm{PGE}_{2} / \mathrm{EP}_{1}$ to long-standing $\mathrm{HKD}$ in mice, in comparison with hypertensive diabetic mice. We present novel data indicating that hypertensive mice (Htn) lacking $\mathrm{EP}_{1}$ receptors $\left(\mathrm{HtnEP}_{1}^{-{ }^{--}}\right)$have worsened renal outcomes despite moderate sustained hypertension also seen in Htn mice. In this regard, $\mathrm{EP}_{1}$ deletion increases albuminuria and reduces GFR in $\mathrm{HtnEP}_{1}^{-1-}$ mice, with prominent injury to podocytes and glomerular endothelium, but the mechanism is unclear. Two major conclusions from this work are that $\mathrm{PGE}_{2} / \mathrm{EP}_{1}$ is protective in $\mathrm{HKD}$, and this effect is independent of BP.

The role of renal $\mathrm{PGE}_{2} / \mathrm{EP}_{1}$ in $\mathrm{BP}$ regulation is multifaceted. $\mathrm{EP}_{1}$ deletion does not impair sodium excretion in the healthy kidney; however, $\mathrm{EP}_{1}^{-1-}$ mice display elevated renin and aldosterone levels consistent with sustained activation of the renin-angiotensin system [32], and an impaired pressor response to angiotensin II [33]. $\mathrm{EP}_{1}^{-1-} \mathrm{DBA} / 1 \mathrm{lacJ}$ mice had lower $\mathrm{BP}$ than $\mathrm{EP}_{1}{ }^{+/+}$mice, and a $0.02 \%$ salt diet lowered BP even further [32]. And in a triple model of nephrectomized-DOCA salt-angiotensin II hypertension, $\mathrm{EP}_{1}$ deletion attenuated the rise in $\mathrm{BP}$ and promoted survival [21]. However, in our model of long-standing moderate hypertension, $\mathrm{EP}_{1}$ deletion did not alter systolic $\mathrm{BP}$, and volume status was maintained in both hypertensive and diabetic-hypertensive mice. Despite this, $\mathrm{EP}_{1}$ deletion worsened albuminuria and reduced GFR in hypertensive null $\left(\mathrm{STZHtnEP}_{1}{ }^{-l-}\right)$. lesions were scored blinded from $0-3+$. Data are presented as mean \pm SEM. $* p<0.05$ vs WT. Data are presented as mean \pm SEM. $* p<0.05$ vs STZ. Line indicates statistical significance between two groups 

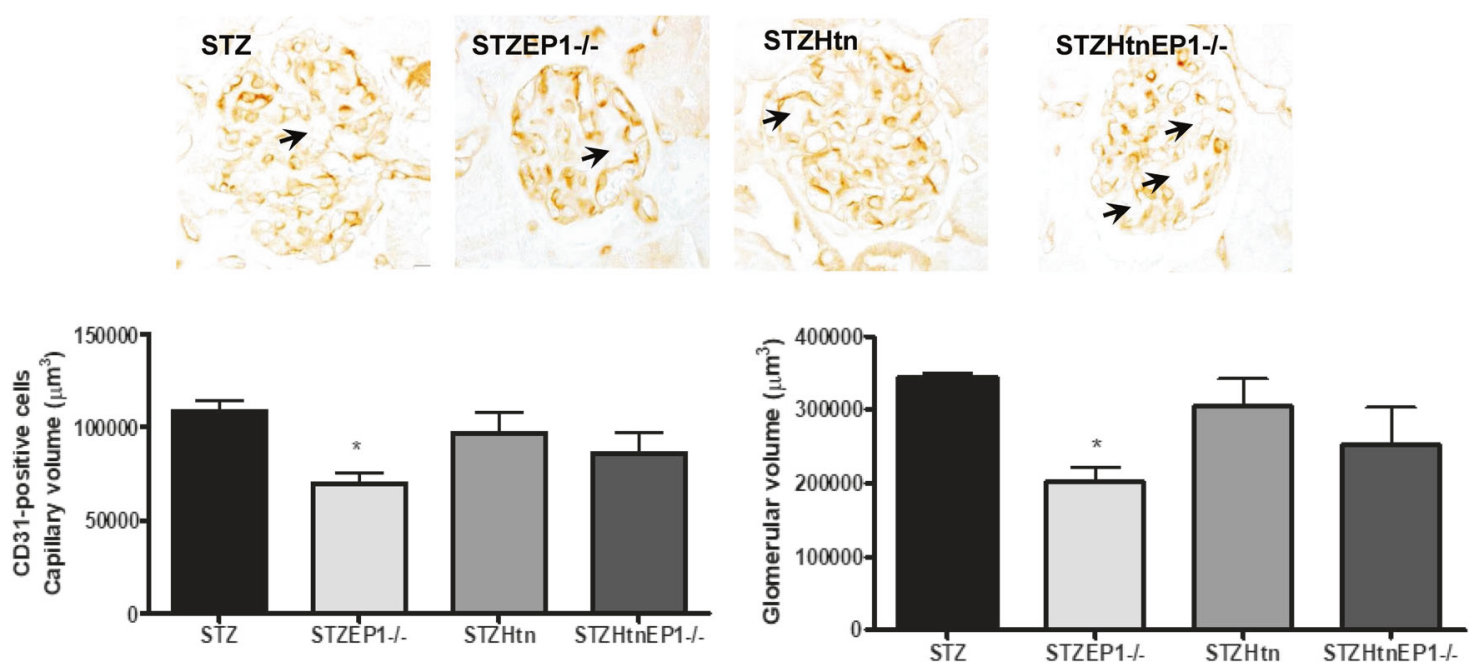

Fig. 7 Representative images of CD31 in glomeruli at 24 weeks of age from four mouse groups with streptozotocin (STZ) diabetes: wild type (STZ), EP ${ }_{1}$ null $\left(\mathrm{STZEP}_{1}{ }^{--}\right.$), hypertensive TTRhRen (STZHtn), and hypertensive $\mathrm{EP}_{1}$ null $\left(\mathrm{STZEP}_{1}^{-l-}\right)$, Zones with absence of CD31 are

mice. It is evident that $\mathrm{EP}_{1}$ is needed to protect against endothelial and podocyte injury in hypertension, as revealed by the ultrastructural injury observed in mice lacking $\mathrm{EP}_{1}$. Indeed, mice lacking $\mathrm{EP}_{1}$ receptors exhibited significantly lower WT1 staining. Moreover, foot process lengths were reduced and GBM was thickened in $\mathrm{HtnEP}_{1}^{-1-}$ mice compared with $\mathrm{EP}_{1}^{-1-}$ mice. The mechanisms resulting in GBM thinning in $\mathrm{EP}_{1}^{-l-}$ and $\mathrm{Htn}$ mice require further clarification, as well as the role of $\mathrm{EP}_{1}$ in foot process length. Interestingly, the HtnEP1 $1^{-/-}$mice displayed lower levels of microparticles than the $\mathrm{EP}_{1}{ }^{-1-}$ mice despite clear podocyte injury. Similar reductions were seen in Annexin $\mathrm{V}^{+}$microparticles. The origin(s) of Annexin $\mathrm{V}^{+}$microparticles in urine is unclear but they likely arise from a mixture of podocytes and various tubular epithelial cell subpopulations. While traditionally, high levels of microparticles are seen with tissue injury, it is possible that the reductions observed here are due to the advanced nature of the injury in in $\mathrm{HtnEP}_{1}{ }^{-l-}$ mice resulting in lower podocyte and tubular cell endowment.

The exact mechanisms were not fully explored in this study, but in the absence of $\mathrm{EP}_{1}$, cortical COX2 is increased and glomerular $\mathrm{EP}_{3}$ and $\mathrm{EP}_{4}$ expression are reduced. Clearly, $\mathrm{EP}_{1}$ may have a role to play in maintaining EP receptor expression, and the loss of these three receptors may have deleterious consequences to the glomerular filtration barrier. Of interest, $\mathrm{EP}_{1}$ deletion did not affect the tubules in hypertensive mice, but in diabetic mice, both $\mathrm{EP}_{1}$ deletion and superimposed hypertension caused similar degrees of tubular dilatation and injury. Despite these tubular effects, transport responses were mostly intact. While $\mathrm{PGE}_{2}$ had no effect on vasopressinstimulated chloride transport in the medullary TAL if

indicated with arrowheads. Capillary volume was estimated from CD31-positive cells and glomerular volumes were measured. Data were shown as mean \pm SEM, $n=3-4$. ${ }^{*} p<0.05$ vs STZ

vasopressin was added first, in the absence of vasopressin $\mathrm{PGE}_{2}$ caused a significant increase in TAL chloride reabsorption. Not only did $\mathrm{PGE}_{2}$ attenuate the magnitude of the vasopressin response when added prior to vasopressin, $\mathrm{EP}_{1}$ mediates this attenuation considering that deletion further reduced the magnitude of the AVP response. The role of specific $\mathrm{PGE}_{2} / \mathrm{EP}$ receptors in TAL transport has not been thoroughly studied. Peterson et al. [34] demonstrated that $\mathrm{PGE}_{2}$ inhibits chloride reabsorption in microperfused rat TAL segments, but the mechanism was not well characterized. Also, in addition to inhibiting AVP-depending chloride reabsorption, $\mathrm{PGE}_{2}$ attenuated AVP-dependent transepithelial voltage in isolated perfused mouse medullary TAL but had no effect on its own [35]. Again, the EP receptors involved, or transport mechanisms were not fully studied. However, $\mathrm{PGE}_{2}$ was shown to inhibit medullary TAL sodium potassium 2 chloride (NKCC2) transport in cultured mouse TAL cells [36]. Though little is known about the $\mathrm{PGE}_{2} / \mathrm{EP}$ pathways mediating TAL responses, we recently confirmed the expression of $\mathrm{EP}_{1,3,4}$ receptors in microdissected mouse TAL by qPCR [22]. It was also shown that $\mathrm{PGE}_{2}$ induces chloride secretion in cultured mouse inner medullary and CCD cells in culture, but the role of CD EP receptors has not been fully characterized $[37,38]$.

We have recently shown that in mouse IMCD, $\mathrm{PGE}_{2} / \mathrm{EP}_{1}$ plays a key role in inhibiting AVP-dependent water reabsorption and determined that the inhibition of sodium transport by $\mathrm{PGE}_{2} / \mathrm{EP}_{1}$ in the $\mathrm{CCD}$ occurs via $\mathrm{ENaC}$ and pendrin-dependent pathways [22]. Consistent with our previous work [22] $\mathrm{PGE}_{2}$ significantly attenuated AVPmediated water reabsorption in the mouse IMCD following 24 weeks of hypertension, and this response was not seen in 
mice lacking $\mathrm{EP}_{1}$. Interestingly, the attenuation of AVPmediated transport by $\mathrm{PGE}_{2}$ was greater in $\mathrm{Htn}$ mice than WT mice, suggesting that the IMCD may be more sensitized to $\mathrm{PGE}_{2}$ or more $\mathrm{PGE}_{2} / \mathrm{EP}_{1}$ receptors are present in Htn IMCD. Another noteworthy finding is that the magnitude of the AVP-mediated water reabsorption is lower in diabetic mice than nondiabetics, but this was not different in all diabetic groups. As in nondiabetic mice, $\mathrm{EP}_{1}$ mediates the attenuation of AVP effects on water transport in response to $\mathrm{PGE}_{2}$. Taken together, the data suggest that $\mathrm{EP}_{1}$ receptors mediate TAL and IMCD transport responses to $\mathrm{PGE}_{2}$, but the transport is unaltered in $\mathrm{Htn}$; and $\mathrm{EP}_{1}$ receptors play a protective role in HKD. The role of $\mathrm{EP}_{1}$ seems to be disease dependent, hypertension versus diabetes, but also the magnitude and duration of hypertension are clearly important as well. Further studies are needed to better understand how in acute malignant hypertension EP1 causes injury, and in moderate long-standing hypertension EP1 is protective. There are several possible explanations, including differences in the contribution of other EP receptors, other prostaglandins, or other hormonal systems that are differentially involved depending on the various models. But future comparisons of these models should help elucidate key differences in pathomechanisms of kidney injury, to offer better therapeutic intervention strategies.

\section{Compliance with ethical standards}

Conflict of interest The authors declare that they have no conflict of interest.

Publisher's note Springer Nature remains neutral with regard to jurisdictional claims in published maps and institutional affiliations.

\section{References}

1. Lim SS, Vos T, Flaxman AD, Danaei G, Shibuya K, Adair-Rohani $\mathrm{H}$, et al. A comparative risk assessment of burden of disease and injury attributable to 67 risk factors and risk factor clusters in 21 regions, 1990-2010: a systematic analysis for the Global Burden of Disease Study 2010. Lancet. 2012;380:2224-60.

2. Olsen MH, Angell SY, Asma S, Boutouyrie P, Burger D, Chirinos JA, et al. A call to action and a lifecourse strategy to address the global burden of raised blood pressure on current and future generations: The Lancet Commission on hypertension. Lancet. 2016;388:2665-712.

3. Harcourt BE, Penfold SA, Forbes JM. Coming full circle in diabetes mellitus: from complications to initiation. Nat Rev Endocrinol. 2013;9:113-23.

4. Nasrallah R, Hassouneh R, Hébert RL. Chronic kidney disease: Targeting prostaglandin E2 receptors. Am J Physiol Renal Physiol. 2014;307:F243-50.

5. Swan CE, Breyer RM. Prostaglandin E2 modulation of blood pressure homeostasis: studies in rodent models. Prostaglandins Other Lipid Mediat. 2011;96:10-3.
6. Gurwitz JH, Avorn J, Bohn RL, Glynn RJ, Monane M, Mogun H. Initiation of antihypertensive treatment during nonsteroidal antiinflammatory drug therapy. JAMA. 1994;272:781-6.

7. Yang T. Microsomal prostaglandin E synthase-1 and blood pressure regulation. Kidney Int. 2007;72:274-8.

8. Whelton A, White WB, Bello AE, Puma JA, Fort JG. Effects of celecoxib and rofecoxib on blood pressure and edema in patients or 65 years of age with systemic hypertension and osteoarthritis. Am J Cardiol. 2002;90:959-63.

9. White WB, Kent J, Taylor A, Verburg KM, Lefkowith JB, Whelton A. Effects of celecoxib on ambulatory blood pressure in hypertensive patients on ACE inhibitors. Hypertension. 2002;39:929-34.

10. Nasrallah R, Hassouneh R, Hébert RL. Prostaglandin E2, kidney disease, and cardiovascular risk: beyond hypertension and diabetes. J Am Soc Nephrol. 2016;27:666-76.

11. Nasrallah R, Robertson SJ, Karsh J, Hébert RL. Celecoxib modifies glomerular basement membrane, mesangial area and podocyte structure in OVE26 mice, but ibuprofen is more detrimental. Clin Sci. 2013;124:685-94.

12. Nasrallah R, Robertson SJ, Hébert RL. Chronic COX inhibition reduces diabetes-induced hyperfiltration, proteinuria, and renal pathological markers in 36-week B6-Ins2(Akita) mice. Am J Nephrol. 2009;30:346-53.

13. Nasrallah R, Xiong H, Hébert RL. Renal prostaglandin E2 receptor (EP) expression profile is altered in streptozotocin and B6-Ins2Akita type 1 diabetic mice. Am J Physiol. 2007;292:278-84.

14. Cherney DZ, Miller JA, Scholey JW, Nasrallah R, Hébert RL, Dekker MG, et al. Renal hyperfiltration is a determinant of endothelial function responses to cyclooxygenase 2 inhibition in type 1 diabetes. Diabetes Care. 2010;33:1344-6.

15. Cherney DZI, Miller J, Scholey JW, Bradley TJ, Slorach C, Curtis $\mathrm{JR}$, et al. The effect of cyclooxygenase 2 inhibition on renal hemodynamic function in humans with type 1 diabetes mellitus. Diabetes. 2008;57:688-95.

16. Cherney DZ, Scholey JW, Nasrallah R, Dekker MG, Slorach C, Bradley TJ, et al. Renal hemodynamic effect of cyclooxygenase 2 inhibition in young men and women with uncomplicated type 1 diabetes mellitus. Am J Physiol Renal Physiol. 2008;294:F1336-41.

17. Thibodeau JF, Nasrallah R, Hébert RL, Kennedy C. Reduced albuminuria in diabetic PTGER1-null mice. Am J Pathol. 2013; 183:1789-802.

18. Makino H, Tanaka I, Mukoyama M, Sugawara A, Mori K, Muro $\mathrm{S}$, et al. Prevention of diabetic nephropathy in rats by prostaglandin E receptor EP1-selective antagonist. J Am Soc Nephrol. 2002;13:1757-65.

19. Rutkai I, Feher A, Erdei N, Henrion D, Papp Z, Edes I, et al. Activation of prostaglandin E2 EP1 receptor increases arteriolar tone and blood pressure in mice with type 2 diabetes. Cardiovasc Res. 2009;83:148-54.

20. Suganami T, Mori K, Tanaka I, Mukoyama M, Sugawara A, Makino H, et al. Role of prostaglandin E receptor EP1 subtype in the development of renal injury in genetically hypertensive rats. Hypertension. 2003;42:1183-90.

21. Bartlett CS, Boyd KL, Harris RC, Zent R, Breyer RM. EP1 disruption attenuates end-organ damage in a mouse model of hypertension. Hypertension. 2012;60:1184-91.

22. Nasrallah R, Zimpelmann J, Eckert D, Ghossein J, Geddes S, Beique JC, et al. PGE2/EP1 receptor inhibits vasopressin-dependent water reabsorption and sodium transport in mouse collecting duct. Lab Invest. 2018;98:360-70.

23. Kennedy CRJ, Xiong H, Rahal S, Vanderluit J, Slack R, Zhang Y, et al. Urine concentrating defect in prostaglandin EP1-Deficient mice. Am J Physiol. 2007;292:F868-75.

24. Araki K, Imaizumi T, Sekimoto T, Yoshinobu K, Yoshimuta J, Akizuki M, et al. Exchangeable gene trap using the Cre/mutated lox system. Cell Mol Biol. 1999;45:737-50. 
25. Thibodeau JF, Holterman CE, Burger D, Read NC, Reudelhuber TL, Kennedy CR. A novel mouse model of advanced diabetic kidney disease. PLoS One. 2014;9:e113459.

26. Hassouneh R, Nasrallah R, Zimpelmann J, Gutsol A, Eckert D, Ghossein J, et al. PGE2 receptor EP3 inhibits water reabsorption and contributes to polyuria and kidney injury in a streptozotocin-induced mouse model of diabetes. Diabetologia. 2016;59:1318-28.

27. Wehbi GJ, Zimpelmann J, Carey RM, Levine DZ, Burns KD. Early streptozotocin-diabetes mellitus downregulates rat kidney AT2 receptors. Am J Physiol Renal Physiol. 2001;280:F254-65.

28. Burger D, Thibodeau JF, Holterman CE, Burns KD, Touyz RM, Kennedy CR. Urinary podocyte microparticles identify prealbuminuric diabetic glomerular injury. J Am Soc Nephrol. 2014;25:1401-7.

29. Raij L, Azar S, Keane W. Mesangial immune injury, hypertension, and progressive glomerular damage in Dahl rats. Kidney Int. 1984;26:137-43.

30. Weibel ER. Sterological Method: Practical Methods of Biological Morphometry. Vol. 1. London: Academic Press; 1979.

31. Himmerkus N, Plain A, Marques RD, Sonntag SR, Paliege A, Leipziger $\mathrm{J}$, et al. AVP dynamically increases paracellular $\mathrm{Na}+$ permeability and transcellular $\mathrm{NaCl}$ transport in the medullary thick ascending limb of Henle's loop. Pflugers Arch - Eur J Physiol. 2017;469:149-58.
32. Stock JL, Shinjo K, Burkhardt J, Roach M, Taniguchi K, Ishikawa $\mathrm{T}$, et al. The prostaglandin E2/EP1 receptor mediates pain perception and regulates blood pressure. J Clin Invest. 2001;107:325-31.

33. Guan Y, Zhang Y, Wu J, Qi Z, Yang G, Dou D, et al. Antihypertensive effects of selective prostaglandin E2 receptor subtype 1 targeting. J Clin Invest. 2007;117:2496-505.

34. Peterson LN, McKay AJ, Borzecki JS. Endogenous Prostaglandin E2 Mediates Inhibition of Rat Thick Ascending Limb CI Reabsorption in Chronic Hypercalcemia. J Clin Invest. 1993;91:2399-407.

35. Culpepper RM, Andreoli TE. Interactions among Prostaglandin E2, Antidiuretic Hormone, and Cyclic Adenosine Monophosphate in Modulating Cl- Absorption in Single Mouse Medullary Thick Ascending Limbs of Henle. J Clin Invest. 1983;71:1588-601.

36. Kaji DM, Chase HS Jr, Eng JP, Diaz J. Prostaglandin E2 inhibits $\mathrm{Na}-\mathrm{K}-2 \mathrm{Cl}$ cotransport in medullary thick ascending limb cells. Am J Physiol Cell Physiol. 1996;271:C354-61.

37. Rajagopal M, Thomas SV, Kathpalia PP, Chen Y, Pao AC. Prostaglandin E2 induces chloride secretion through crosstalk between cAMP and calcium signaling in mouse inner medullary collecting duct cells. Am J Physiol Cell Physiol. 2014;306:C263-78.

38. Sandrasagra S, Cuffe JE, Regardsoe EL, Korbmacher C. PGE2 stimulates $\mathrm{Cl}$ - secretion in murine $\mathrm{M}-1$ cortical collecting duct cells in an autocrine manner. Pflügers Arch. 2004;448:411-21. 